\title{
Responses to Salduz: Procedural Tradition, Change and the Need for Effective Defence
}

\author{
John D. Jackson*
}

This article examines the responses of national courts to the ECtHR's decision in Salduz $\mathrm{v}$ Turkey that suspects be provided with access to a lawyer before they are first interrogated by the police. It argues that harmonious application of human rights standards in criminal proceedings should build upon common values underpinning the procedural traditions of member states. ECtHR success in gaining acceptance for the principle of access to a lawyer during police interrogation, anchoring it in the privilege against incrimination, is contrasted with resistance towards giving the defence any active role during criminal investigations. It is argued that this resistance can be overcome by an appeal to safeguards that have long dominated the trial process. As the investigation phase increasingly determines the outcome of criminal proceedings, standards of fairness traditionally reserved for the trial process should be applied also to this phase in order to provide suspects with an effective defence.

\section{INTRODUCTION}

This article aims to explore the response of national courts towards the European Court of Human Rights (ECtHR)'s decision in Salduz v Turkey ${ }^{1}$ (Salduz) affirmed soon afterwards in a number of other decisions, ${ }^{2}$ that suspects be provided with access to a lawyer before they are first interrogated by the police. Commentators have remarked upon the rapidly changing position across Europe in the light of the Salduz decision as a number of jurisdictions have introduced a clear right to legal assistance at the early stages of police investigation when they were previously reluctant to do so. ${ }^{3}$ Within the 'inquisitorial' tradition especially there has long been an attachment to a model of custodial interrogation which excludes the defence. ${ }^{4}$ Salduz

\footnotetext{
*University of Nottingham. This is a revised version of a paper presented at the EU Criminal Justice Conference, 'On the Road to a EU Criminal Justice System: Problems, Achievements and Prospects' at the University of Limerick, 21-22 May 2015. Thanks are due to Dimitrios Giannoulopoulos, Máximo Langer, Paul Roberts, Sarah Summers, Thomas Weigend, and the anonymous referees for comments on earlier drafts. All errors are my own responsibility.
}

1 (2009) 49 EHRR 421.

2 See, for example, Panovits v Cyprus [2008] 27 BHRC 464, Aslan and Demir v Turkey ECtHR 17 February 2009, Oztürk v Turkey ECtHR 7 February 2009, Aba v Turkey ECtHR 3 March 2009, Böke and Kandemir v Turkey ECtHR 10 March 2009, Dayanan v Turkey ECtHR 13 October 2009, Pishchalnikov v Russia ECtHR 24 December 2009, Brusco v France ECtHR 14 October 2010.

3 E. Cape, Z. Namoradze, R. Smith and T. Spronken, Effective Criminal Defence in Europe (Antwerp: Intersentia, 2010) 584.

4 See J. Hodgson, 'The Police, the Prosecutor and the Juge d'Instruction: Judicial Supervision in France, Theory and Practice' (2001) 41 BJ Crim 342, 359; D. Giannoulopoulos, 'Custodial Legal Assistance and Notification of the Right of Silence in France: Legal Cosmopolitanism and Local Resistance' (2013) 24 Criminal Law Forum 291. 
can be represented as a triumph of 'cosmopolitan' jurisprudence which is encouraging national courts to engage in a transnational judicial dialogue that reaches out beyond their domestic legal cultures and traditions. ${ }^{5}$ But when we dig a little below the surface, a more confused picture emerges. There may have been a recognition of the principle of access but there are very different conceptions about the scope of the right of access and what role lawyers should in practice play when they obtain access. ${ }^{6}$ In arguing the need for an EU Directive to ensure a sufficient and consistent level of compliance with the Salduz doctrine, the European Commission claimed that the ECtHR rulings had been interpreted differently by different courts and where courts and legislatures had attempted to bring procedures into line with the European Convention on Human Rights (ECHR) they had done so in a piecemeal fashion that had been reactive rather than proactive. ${ }^{7}$ The Commission's proposal for a Directive was itself, however, subject to an avalanche of criticism by certain states and led to considerable negotiation with the final agreement falling short of the original proposal in a number of respects. ${ }^{8}$ This illustrates the difficulties in achieving a harmonious application of human rights standards in criminal proceedings across the member states of the ECHR and the EU.

Looking back on more than six years of practice since the landmark Salduz ruling, it will be argued that for the ECtHR to be successful in achieving this aim, it must respond to the "quotidian demands of local conditions "on the ground", by building upon common values so that the changes it wishes to make are firmly embedded within procedural traditions. The ECtHR's success in gaining acceptance for the principle of access to a lawyer during police interrogation can be attributed to the court founding it upon the well-established privilege against self-incrimination. But whatever the soundness of basing the principle upon this rationale, the privilege against self-incrimination does not explain the need for the more active defence role that the court and the EU institutions would seem to envisage at this stage. For this vision to be truly realised, it will be suggested that there needs to be an understanding of why

5 For the increasing tendency of judges to engage in transnational dialogue, see G. Canivet, 'Trans-judicial Dialogue in a Global World' in S. Muller and S. Richards (eds), Highest Courts and Globalisation (The Hague: Hague Academic Press, 2010). For examples within criminal jurisprudence, see P. Roberts, 'Introduction' in P. Roberts, Theoretical Foundations of Criminal Trial Procedure (Farnham: Ashgate, 2014) xxxii.

6 For a recent study, see J. Blackstock, E. Cape, J. Hodgson, A. Ogorodova and T. Spronken, Inside Police Custody: An Empirical Account of Suspects' Rights in Four Jurisdictions (Antwerp: Intersentia, 2014).

7 European Commission, Impact Assessment Accompanying the Proposal for a Directive on the Right of Access to Lawyer 20110, 8 June 2011, SEC (2011) 687 final, para 3.4.2.

8 See Directive 2013/48/EU of the European Parliament and the Council of 22 October 2013 on the right of access to a lawyer, OJ 6.11.2013 (L 294). See I. Anagnostopoulos, 'The Right of Access to a Lawyer in Europe: A Long Road Ahead?' (2014) 4 European Criminal Law Review 3; J. Jackson, 'Cultural Barriers on the Road to Providing Suspects with Access to a Lawyer' in R. Colson and S. Field (eds), EU Criminal Justice and the Challenges of Diversity (Cambridge: CUP, 2016) 181.

9 P. Roberts, 'Faces of Justice Adrift? Damaška's Comparative Method and the Future of Common Law Evidence' in J. Jackson, M. Langer and P. Tillers (eds), Crime, Procedure and Evidence in a Comparative and International Context: Essays in Honour of Mirjan Damaška (Oxford: Hart, 2008) 328. 
what has traditionally been viewed as an investigatory phase of proceedings is increasingly becoming in effect an adjudicatory phase requiring 'adversarial' safeguards reaching beyond the privilege against self-incrimination that are embedded in the procedural traditions of member states but have traditionally been reserved for later phases of the criminal process.

We will first examine briefly the two procedural traditions that are commonly associated with the member states of the Council of Europe and the European Union and how these came to embrace the principle of defence participation in criminal proceedings. We will then consider how the ECtHR has succeeded in gaining acceptance for the principle of access to a lawyer during police interrogation. Finally, we will illustrate how the application of this principle has fallen short of the vision of an active defence that the ECtHR has set out and, it will be argued, needs to be realised as the investigation phase increasingly determines the outcome of the proceedings.

\section{PROCEDURAL TRADITION AND THE PRINCIPLE OF DEFENCE PARTICPATION}

The view that there are two dominant procedural traditions within Europe rooted in the separate common law and civil traditions is one that is widely shared within comparative criminal procedural scholarship, although how exactly these traditions should be characterised and what labels should be given to them is much more contested. ${ }^{10}$ It has been argued that the difficulties in reaching agreement as to what the procedural elements of each tradition are or on what the labels commonly used to describe them - 'adversarial', 'accusatorial' and 'inquisitorial' - actually mean should not deflect us from recognising that there are two distinct procedural traditions whose importance should not be under-estimated as we identify common policies and practices being developed across different systems and as a cosmopolitan law appears to extend beyond the reach of these traditions. ${ }^{11}$ In his study of plea bargaining, Langer has argued that 'adversarial' and 'inquisitorial' procedural structures of interpretation and meaning are not only the 'lenses' through which legal actors understand and operate in reality, they also constitute two normative orders that indicate, to a certain extent, how cases should be handled, what technologies should be used and how actors of the system should behave. ${ }^{12}$ His empirical claim that the adversarial and inquisitorial cultures remain highly predominant in AngloAmerican and civil law jurisdictions of continental Europe and Latin America

10 One of the best analyses of the way both continental and Anglo-American scholarship has traditionally used expressions such as 'adversarial' or 'accusatorial' or 'inquisitorial' procedure is to be found in M. R. Damaška's seminal article on comparative criminal justice, 'Evidentiary Barriers to Conviction and Two Models of Criminal Procedure' (1973) 121 University of Pennsylvania Law Review 506, 554-578.

11 S. Field, 'Fair Trials and Procedural Tradition' (2009) 29 OJLS 365.

12 M. Langer, 'From Legal Transplants to Legal Translations: The Globalisation of Plea Bargaining and the Americanization Thesis in Criminal Procedure' (2004) 45 Harvard International Law Journal 1. 
respectively does not preclude the possibility of change within these cultures. But he tends to view change, as in the introduction of 'plea bargains', known as 'Absprachen', in Germany which used to be 'a land without plea bargaining, ${ }^{13}$ in terms of a struggle between different interpretations of meaning and different actors with internal dispositions that correspond to these structures of meaning.

Others see the prospect of change as built into the very notion of the two procedural traditions. Borrowing from Patrick Glenn's analysis of legal tradition, ${ }^{14}$ Field argues that we should expect 'adversarial' and 'inquisitorial' traditions to bear only a contingent relationship to actual current practices. ${ }^{15}$ Traditions are constantly being re-interpreted. This does not mean that the inquisitorial and adversarial concepts are 'outdated'; rather they are continually being reshaped by national and transnational social and legal movements and they remain important to an analysis of contemporary legal cultures because the past continues to act upon the present. Like Langer, Field brings change into the centre of his analysis. Tradition for Field, like culture for Langer, should not be seen as some kind of unchanging homogeneous 'life form'. When it comes to quantifying the impact particular changes have had on procedural tradition, however, there is a methodological problem of how exactly to do the measurement when the terms used to describe the traditions - adversarial, accusatorial, inquisitorial - are so contestable while yet exerting such a powerful influence over the terms of the debate. If the traditions are constantly adapting in clashes with 'outside' forces such as drives for efficiency, accountability, austerity or human rights, when are we to know whether like the Trojan horse such forces have succeeded in undermining the tradition or whether tradition has succeeded in accommodating the change and defeating the enemy at the gate?

One way of answering this question is to consider the extent to which change undermines the underlying values underpinning the tradition. Unlike cultures which tend to emphasise difference, ${ }^{16}$ traditions borrow from each other and are in constant contact, each containing elements of the other. ${ }^{17}$ According to Glenn, this does not mean that 'in all traditions, all is subject to negotiation'. He contends that the identity of a tradition is best thought of in 'triptych form'. ${ }^{18}$ The overall identity of a tradition constitutes its total information base and includes many internal dissenting elements. There is within this a 'leading' or 'primary' version of the tradition which at any given time appears accepted as its truest version. But there is also, thirdly, the 'underlying' or 'basic' element or elements, 'those without which no other elements would stand' and when there is change to these elements, this would appear to bring the tradition to an

13 ibid, 39, citing, at n 182, J. H. Langbein, 'Land Without Plea Bargaining: How the Germans Do It' (1979) 78 Michigan Law Review 204.

14 H. P. Glenn, Legal Traditions of the World: Sustainable Diversity in Law (Oxford: OUP, $5^{\text {th }}$ ed, 2014).

15 Field, n 11 above.

16 H. P. Glenn, 'Legal Cultures and Legal Traditions' in M. Van Hoecke (ed), Epistemology and Methodology of Comparative Law (Oxford: Hart, 2014) 7, 17. For discussion of 'culture' and 'tradition' as organising concepts, see W. Twining, General Jurisprudence (Cambridge: CUP, 2009) 79-86.

17 Glenn, n 14 above, 39.

18 ibid. 
end. A particular change may not fundamentally affect the tradition as it can be adapted, as Glenn has put it, within the overall 'bran-tub'. ${ }^{19}$ The blending that takes place may thus be relatively harmonious. To use another analogy, as cream is poured into coffee, the coffee may retain its overall coffee-like identity. ${ }^{20}$ But the tradition is fundamentally endangered when it accepts something totally alien or when, over time, the basic tenets of the tradition lose their force or persuasion and this is likely to occur, according to Glenn, in tandem with the growth in adherence to another tradition. Sometimes, however, it would seem that change can affect a tradition profoundly without fundamentally changing its basic values. Traditions are necessarily connected and bound up with each other. Some of the basic underlying elements within a procedural tradition are represented in terms of fundamental values that are shared with other traditions and the need to preserve or accommodate these may help to explain why changes may require well-established procedural traditions to re-invent themselves in order to remain true to a deeper identity with these values and goals.

The changes that occurred to continental and English criminal procedure during the nineteenth century which included the use of defence counsel in both types of trial procedure may be characterised as requiring a re-branding of the accusatorial and inquisitorial traditions which had been the dominant procedural traditions in Europe up to this time. The need for change was prompted by a perception that these traditions were failing to adhere to the key values of truth finding and due process. Although the traditions had not entirely neglected the need for truth finding and due process, they had become dependent on practices that were increasingly seen as out of tune with the Enlightenment thinking of the time. ${ }^{21}$ At the dawning of the French Revolution both continental and Anglo-Saxon systems were so clearly lacking in legitimacy by failing to give expression to these values that change had to be embraced. Many of the features of the old 'inquisitorial' procedural style, such as the system of legal proofs and the use of torture, became incompatible with the changing political and social climate and 'accusatorial' features began to emerge in a reformed continental procedure, notably the transmission of the dossier to a public prosecutor, who decided whether to bring the case to trial, followed by a public trial at which both prosecution and defence were given an opportunity for argument and debate. ${ }^{22}$ Although Enlightenment thinkers looked across the Channel towards the Anglo-Saxon system for inspiration, this system was also suffering

19 ibid, 41.

20 D. Westbrook, 'Theorising the Diffusion of Law: Conceptual Difficulties, Unstable Imaginations, and the Effort to Think Gracefully Nonetheless' (2006) 47 Harvard International Law Journal 489, 491. It may be unclear at first how new 'mixes' will work out, like a baked cake, where the outcome is not known until the cake is fully baked. At some point, however, it should be possible to say whether the cake has retained the purity of the individual ingredients that one started out with - its lemonness, or orangeness etc - or whether the infusion of new ingredients - coffee, chocolate, or whatever - has changed its overall identity. See E. Örücü, 'A General View of "Legal Families" and of "Mixing Systems"” in E. Örücü and D. Nelken (eds), Comparative Law: A Handbook (Oxford: Hart, 2007).

21 For the influence of due process on the inquisitorial tradition that emerged from medieval continental criminal procedure, see M. R. Damaška, 'The Quest for Due Process in the Age of Inquisition' (2012) 60 AJCL 919.

22 Damaška, n 10 above, 558-559. 
from a lack of legitimacy. The lack of any machinery for investigating cases before trial and the disadvantages defendants suffered by being subjected to questioning by the judge in a 'trial by altercation' without any legal representation meant that the system suffered from both truth and fairness deficits. ${ }^{23} \mathrm{Grad}-$ ually, during the course of the nineteenth century prosecutions came to be overseen by either the police, clerks to magistrates or borough solicitors financed out of public funds and the rise of independent counsel representing the prosecution at trial led to a corresponding rise in counsel representing the defence, albeit that a right to legal aid was not introduced until the early twentieth century. ${ }^{24}$

These changes led scholars to re-characterise the procedural traditions within continental and English criminal procedure. Scholars on the continent increasingly referred to their mode of procedure as a 'mixed' system consisting of a mixture of accusatorial and inquisitorial elements while Anglo-American commentators used the term 'adversarial' rather 'accusatorial' to highlight the combative nature of party proceedings which arose from the introduction of lawyers representing the parties. ${ }^{25}$ There were differences of emphasis between continental and Anglo-American scholars in the way in which they characterised the introduction of defence participation into their respective traditions. Continental jurists saw the change as heralding the development of a new 'accusatorial trinity' whereby the parties were given an opportunity to participate in trial proceedings and convince the court of their position. ${ }^{26}$ Ultimately, however, the criminal proceeding remained a judicial inquiry and this conception of judicial authority remains influential to this day in continental procedures. Even in greatly reformed procedures, such as Italy which has given the defence considerable power to carry out parallel investigations to those of the public prosecutor, the accusatorial system recoils from the Anglo-American model of adversary, party domination of the proceedings. ${ }^{27}$ Anglo-American commentators, on the other hand, emphasised the fact that adversarial procedure imposes considerable constraints on the judge, limiting the scope for searching for the truth and being dependent on the material introduced by the parties. ${ }^{28}$

This meant that the defence role was conceived somewhat differently in each tradition. The 'adversarial' tradition conjures up the notion of a battle with two opponents attempting to strike each other down, by means of excluding their evidence so that their opponent has less armoury, then actively presenting and challenging evidence through the examination and cross-examination

23 See J. Langbein, The Origins of the Adversary Criminal Trial (Oxford: OUP, 2003) 13-16.

24 See Poor Prisoners' Defence Act 1903. For an account of how legal representation came to be introduced in English trials during the $19^{\text {th }}$ century, see D. Bentley, English Criminal Justice in the Nineteenth Century (London: Hambledon, 1998) 125-130.

25 Damaška, n 10 above, 558. See also M. R. Damaška, 'Models of Criminal Procedure' (2001) 51 Zbornik (Collected Papers of Zagreb Law School) 477, 490.

26 S. Summers, Fair Trials: The European Criminal Procedural Tradition and the European Court of Human Rights (Oxford: Hart, 2007) 24-29.

27 G. Illuminati, 'The Accusatorial Process from the Italian Point of View' (2010) 35 North Carolina Journal of International \& Commercial Regulation 297.

28 M. Ploskowe, 'The Development of Present-Day Criminal Procedures in Europe and America' (1935) 48 Harvard Law Review 433; G. Van Kessel, 'Adversary Excesses in the American Criminal Trial' (1992) 67 Notre Dame Law Review 403, 527-531. 
of evidence, with the judge playing an 'umpireal' role. ${ }^{29}$ The mixed 'inquisitorial/accusatorial' or, as some have described it, 'non-adversarial' tradition, ${ }^{30}$ on the other hand, embraced a different notion of proofs being contradicted by the arguments of all participants who play the role of co-pilots who may go off in different directions but with the judge remaining very much at the helm. ${ }^{31}$ The contradictoire principle can accommodate the idea of certain evidence not being able to be used but such evidence will still be revealed to the judicial triers of fact who remain charged with examining all the available evidence.

Although the way in which evidence is to be presented and challenged by the parties is differently conceived, however, a consensus gradually emerged within both traditions that defence counsel should represent accused persons during criminal proceedings and in the twentieth century such a right became embedded into international human rights law in various human rights instruments. Built into the wording of Article 6(3)(c) of the ECHR that defendants can choose to defend themselves or through legal assistance of their own choosing is the notion that counsel is there at the personal choice and as the personal representative of the accused, in a protective capacity and offering an effective mouthpiece for the accused, should he or she choose to exercise the right of counsel. But it has also been argued that the right provides the 'key' which opens the door to all the rights and possibilities of the defence in a substantive sense, suggesting that counsel not only acts as a mouthpiece for the defendant but is there to provide an active defence against the charges laid. ${ }^{32}$ This notion of 'active defence' appears to straddle both adversarial and non-adversarial traditions and is reflected in what the ECtHR has described in numerous decisions as the principles of 'equality of arms' and 'adversarial procedure'. These principles are respectively defined as giving the parties a reasonable opportunity to present their case in conditions that do not place them at substantial disadvantage vis-à-vis their opponent and giving them an opportunity to have knowledge and comment on the observations filed and the evidence adduced by the other party. ${ }^{33}$

\section{ACCESS TO A LAWYER DURING POLICE INVESTIGATION BEFORE} $S A L D U Z$

If a consensus emerged across the traditions that defendants were entitled to an 'active defence' during the criminal trial proceedings in order to engage fully in

29 A. Ryan, Towards a System of European Criminal Justice (Abingdon: Routledge, 2014) 81.

30 See, for example, Damaška, n 10 above.

31 See also Grande's use of different dance styles - the 'tango' and the 'rumba' - to characterise the two procedural forms: E. Grande, 'Dances of Criminal Justice: Thoughts on Systemic Differences and the Search for Truth' in Jackson et al, n 9 above, 145.

32 S. Trechsel, Human Rights and Criminal Proceedings (Oxford: OUP, 2005) 245. The way in which the role of defence counsel is conceived has implications for whether an 'absent' accused is entitled to legal assistance: see Naziraj v Germany ECtHR 8 Nov 2012.

33 J. D. Jackson, 'The Effect of Human Rights on Criminal Evidentiary Processes: Towards Convergence, Divergence or Realignment?' (2005) 68 MLR 737. 
'adversarial' argument, there was no such acceptance in either tradition that suspects should be entitled to any active defence during the investigatory phase of the proceedings. As accused persons became increasingly subject to questioning during this phase, certain nineteenth century scholars argued that 'accusatorial' features should be introduced in this phase as well as at trial. But legislators and judges rejected such an idea on the ground that this would compromise the effectiveness of the investigation. ${ }^{34}$ At common law, those committed for trial could hire lawyers to prepare for trial if prison rules allowed access. But there was no recognition of any right to legal assistance during the preliminary investigation conducted by magistrates in the early part of the $19^{\text {th }}$ century, although this changed when magistrates ceased to exercise investigative functions under Jervis's Indictable Offences Act 1848. ${ }^{35}$ In France the law of 1897 extended the right to be assisted by a lawyer to the pre-trial phase where interrogations were conducted by the juge d'instruction. Lawyers could be present during the interrogation but the object of the lawyer's presence was to exercise control over any abuse of process by the juge rather than to engage in any debate with the judge. ${ }^{36}$ In Germany and Italy the role of the lawyer was even more restricted during the instruction phase. Defendants could be advised by lawyers but lawyers could not be present when they were questioned. ${ }^{37}$ Gradually, the role of the defence expanded to incorporate the principle of contradictoire into the instruction phase ${ }^{38}$ But there was no acceptance in either tradition that lawyers could be present during any questioning by the police who were increasingly given an important role in criminal investigation across the traditions. ${ }^{39}$

Instead what was important at the pre-trial investigation phase was that any participation by suspects should be voluntary and of their own free will. The voluntariness principle, whereby any statements induced by promises or threats held out by persons in authority could not be admitted as evidence, became well established in common law jurisdictions throughout the nineteenth century. ${ }^{40}$ Other jurisdictions across the traditions prohibited the use or threat of force or violence and other forms of coercion against suspects in custody and excluded confessions so obtained. ${ }^{41}$ Gradually, this led to a recognition of the right of

34 Summers, n 26 above, 83 .

35 See Bentley, n 24 above, 31-32, 40-41, Summers, ibid, 87 citing Cox v Coleridge (1822) 1 B \& C 37, 54-55. In Scotland, the Criminal Procedure (Scotland) Act 1887, s 17 recognised a right to consult a law agent who could be present during judicial examination. See F. Leverick, 'The Right to Legal Assistance during Detention' (2011) 15 Edinburgh Law Review 353.

36 See M. Ploskowe, 'The Investigating Magistrate (Juge d'Instruction) in European Criminal Procedure' (1935) 33 Michigan Law Review 1010, 1015.

37 ibid, 1016.

38 This did not happen everywhere however. For example, in Belgium defence counsel had no right to be present when the accused was questioned or witnesses were examined. See C. Van Den Wyngaert (ed), Criminal Procedure Systems in the European Community (London: Butterworths, 1993) 16.

39 See E. A. Tomlinson, 'Nonadversarial Justice: The French Experience' (1983) 42 Maryland Law Review 131, 167, arguing that the 'rights of the defence' do not apply at all during the earlier stage of a police inquiry and stating that it is contrary to the ethics of French lawyers to have any contact with the judicial police on behalf of a client during the course of a police inquiry.

40 The rule dates back to $R$ v Warickshall (1783) 1 Leach 263. For a survey of the history of this rule, see P. Mirfield, Confessions (London: Sweet \& Maxwell, 1985) 42.

41 For a survey of the law, see C. M. Bradley, 'The Emerging Consensus as to Criminal Procedure Rules' (1993) 14 Michigan Journal of International Law 171; G. Van Kessel, 'European Perspectives 
silence and a right for suspects to be informed of such a right, although there were variations in the way this right was communicated to suspects. From 1848 in England and Wales magistrates were additionally required to warn suspects prior to taking a statement from them that whatever they said may be given against them at their trial, which appeared to be a stronger reinforcement of the right to silence than merely telling suspects that they may remain silent. ${ }^{42}$ When the police took over criminal investigations from magistrates, they were at first prohibited from questioning suspects but were later permitted to do so under Judges' Rules, provided cautions were issued warning suspects that they did not have to answer questions. ${ }^{43}$ Although the right of silence is of more recent vintage on the continent as it jarred with the traditional view that suspects were expected to participate in the investigatory phase of inquisitorial procedure, ${ }^{44}$ gradually throughout the 20 th century it became accepted as a key protection for suspects who were detained in custody, so that by the end of the century many, although not all, jurisdictions provided that an accused be told of the right to remain silent both during pre-trial questioning and at trial. ${ }^{45}$

By the 1990s the ECtHR came to rule on its importance by stating in a number of decisions that the privilege against self-incrimination and the right to silence are 'generally recognised international standards which lie at the heart of the notion of a fair procedure under art 6'. ${ }^{46}$ Taking its cue from the emphasis placed in national jurisdictions on the need for any accused's participation in the criminal process to be voluntary, the court considered that one of the rationales of the privilege was for the prosecution in a criminal case to seek to prove their case against the accused without resort to evidence obtained through methods of coercion and oppression in defiance of the will of the accused. Such a right exists from the moment a person is 'charged' with

on the Accused as a Source of Testimonial Evidence' (1998) 100 West Virginia Law Review 799, $804-805$.

42 Summers, n 26 above, 85 .

43 For a history of the Judges' Rules and the Administrative Directions that accompanied them, see Royal Commission on Criminal Procedure, Law and Procedure Cmnd 8092-1 (1981), Appendix 13.

44 Damaška, n 10 above, 527, Van Kessel, n 28, above 842.

45 See, for example, Germany Code of Criminal Procedure (CCP), Art 136.1; Italy CCP, Art 64.3; Spain CCP, Art 520.2a. See generally Giannoulopoulos, n 4 above, 303-306. In France notification of the right of silence was not required until 2000 but this was replaced in 2002 by a law which informed the suspect only of a number of options including a right of silence and the following year the obligation was removed altogether until 2011. See J. Hodgson, French Criminal Justice (Oxford: Hart, 2005) 12; Giannoulopoulos, ibid, 300-302. In Belgium the right of notification was only introduced in 2011 under the Law of 13 August 2011, Art 2. See Giannoulopoulos, ibid, 305. Although the CCP of 1926 in The Netherlands required that suspects be warned of their right of silence, this requirement was abolished in 1934 and the caution was only reinstated in 1974. See C. Brants, 'The Reluctant Dutch Response to Salduz' (2011) Edinburgh Law Review 298. There were also differences between jurisdictions as to the scope of these requirements. See Van Kessel, n 41 above, 808, making the point that in Germany and England warnings must be given to suspects who are being investigated, not necessarily in custody, and in Italy even those who are not under arrest or investigation must be cautioned as soon as they begin to make inculpatory statements.

46 Funke v France (1993) 16 EHRR 297at [41]-[44], Saunders v United Kingdom (1997) 23 EHRR 313 at [68], John Murray v United Kingdom (1996) 22 EHRR 29 at [45], Heaney and McGuinness v Ireland (2001) 33 EHRR 12 at [40], Getiren v Turkey ECtHR 22 July 2008 at [123]. 
a criminal offence, which has been interpreted to mean when the person is formally charged with an offence or has otherwise been notified that he or she is suspected of an offence. ${ }^{47}$ Interestingly, however, it took some time before the court came to affirm the need for suspects to be informed of their right of silence before being questioned by the police. ${ }^{48}$

While the right of silence has gradually become a well-established principle across the procedural traditions and is now reinforced by international human rights jurisprudence, ${ }^{49}$ there was greater reluctance across the procedural traditions to accede to any right of access to a lawyer at the stage of police questioning. However, from the mid-twentieth century there were gradual signs of such a right becoming recognised primarily as a means of giving recognition to the right of silence. Within the adversarial tradition the right of access at the stage of police questioning became famously associated with the privilege against self-incrimination when the United States Supreme Court (USSCt) required in Miranda v Arizona ${ }^{50}$ (Miranda) that prior to any questioning suspects had to be warned not only of their right to silence but of their right to the presence of an attorney. The USSCt affirmed that the Fifth Amendment privilege was available outside of criminal court proceedings and served to protect persons in all settings in which their freedom of action is curtailed in any significant way from being compelled to incriminate themselves. ${ }^{51}$ The court concluded that without proper safeguards the process of in-custody interrogation of persons suspected or accused of crime contained inherently compelling pressures which work to undermine the individual's will to resist and compel him to speak where he would not otherwise do so freely. The court did not want to be over-prescriptive about the various ways in which the privilege could be protected but it considered that a number of safeguards had to be observed: notification of the right of silence; an explanation that anything said can and will be used against the individual in court; and, crucially, mindful of the fact that the circumstances surrounding in-custody interrogation can operate to overbear the will of one merely made aware of the privilege, the right to have counsel present at the interrogation; notification of the right to consult a lawyer and to have him or her present during interrogation; and the right of indigent persons to have a lawyer appointed to represent him. ${ }^{52}$ The right of access was deliberately framed in terms of the need for the lawyer to be

47 Deweer v Belgium (1979-80) 2 EHRR 439 at [46], Pederson and Baadsgaard v Denmark ECtHR 17 Dec 2004.

48 Zaichenko v Russia ECtHR 18 Feb 2010 at [52]. Trechsel considers that the absence of applicants' claims based on the need for a caution explains the lack of case law on the point. In order to be successful on the basis of such a claim the applicant would have to claim that he or she was mainly convicted on the basis of statements made as a result of waiving the right to remain silent, such waiver not being valid because he or she was not properly informed of the right to remain silent. See n 32 above, 352.

49 Although the ECHR does not give express recognition to the privilege against selfincrimination, the International Covenant on Civil and Political Rights, Art 14 (3)(g) states that everyone shall be entitled not to be compelled to be a witness against himself or to plead guilty.

50 (1965) 384 US 436.

51 ibid, 467.

52 ibid, 467-473. 
present during questioning because 'the need for the lawyer to protect the Fifth Amendment in the environment of a secret interrogation process comprehends not merely a right to consult with counsel prior to questioning, but also to have counsel present during any questioning if the defendant so desires'. ${ }^{53}$

What comes across unmistakeably from the judgment is the manner in which justification for the presence of a lawyer is instrumentally tied to the privilege and the need to protect the suspect from speaking when he would not otherwise do so freely. Crucially, the presence of a lawyer is limited to situations where the suspect is going to be interrogated and there is no right of access unless there is going to be an interrogation. ${ }^{54}$ The court did accept that the lawyer's presence at the interrogation may serve other subsidiary functions as well: mitigation of the dangers of untrustworthiness if the accused decides to talk, reduction of coercion, and the need for any statement made to the police to be accurate and for it to be accurately reported by the prosecution at trial. ${ }^{55}$ These functions are primarily about protecting the accused from the dangers of his or her participation in the interrogation and there was no attempt to assimilate counsel's role here with the kind of active defence role that lawyers are expected to play at trial. This point was illustrated, if only indirectly, when the court went on to hold that just as at trial there is no need for an accused to make a request for a lawyer, so an individual need not make a pre-interrogation request for a lawyer, adding that: 'Although the role of counsel at trial differs from the role during interrogation, the differences are not relevant to the question whether a request is a prerequisite'. ${ }^{56}$

The USSCt interestingly sought to justify its position by making reference to similar changes that were taking place within the common law tradition. It proclaimed that the 1964 version of the English Judges' Rules expressly recognised the right of an individual to consult with an attorney while under questioning by the police. ${ }^{57}$ In fact such a principle was highly qualified and it stopped short of any right for a solicitor to be present when a person in custody is being questioned. ${ }^{58}$ It was not until the Police and Criminal Evidence Act was enacted in 1984 that there was any meaningful recognition in England and Wales of a suspect's right to consult a solicitor at any time on request while in detention. ${ }^{59}$

This legislation was enacted against the background of the recommendations of a Royal Commission which had been tasked to find an appropriate balance between the interests of the community in bringing offenders to justice and

53 ibid, 470.

54 See Van Kessel, n 41 above, 837 citing Duckworth v Eagan (1989) 492 US 195, which held that Miranda does not require that lawyers be producible on call, but only that a suspect be informed that he has a right to counsel before and during questioning.

55 n 50 above, 470.

56 ibid, 471.

57 ibid, 488.

58 Principle (c) of the Judges' Rules stated that 'every person at any stage of an investigation should be able to communicate and to consult privately with a solicitor' even if in custody provided that 'in such a case no unreasonable delay or hindrance is caused to the processes of investigation or the administration of justice by his doing so'.

59 Police and Criminal Evidence Act 1984 (PACE), s 58 states that 'a person arrested and held in custody in a police station ... shall be entitled if he so requests, to consult a solicitor privately at any time'. 
the rights and liberties of persons accused or suspected of crime. ${ }^{60}$ Such a wide-ranging review of criminal procedure had in turn been prompted by an inquiry that had pointed to a miscarriage of justice in the case of three youths who had confessed to crimes which they had not committed in police custody in the absence of legal advice. ${ }^{61}$ The Royal Commission gave particular attention to the importance of the right to legal assistance as a means of providing the suspect with advice on the legal intricacies of her situation, which included but was not limited to advising on the full implications or the desirability of exercising her right of silence. For this reason it considered that the power to refuse access should be exercised only in exceptional cases and should not be refused because a solicitor may advise his client not to speak. ${ }^{62}$ The Commission also considered that the practice of having a solicitor present at interview should be encouraged but it emphasised that he should have no wider formal function than to offer the suspect advice if requested. ${ }^{63}$

Developments in Scotland took a different turn. There, too, the police had resorted to questioning suspects before arrest and charge but doubts about the legal basis for holding suspects for questioning before they were arrested and brought before a sheriff for judicial examination persuaded the Thomson Committee in 1975 to recommend that the police be given a six hour period to detain a person for questioning where there were grounds for suspecting he had committed an offence punishable by imprisonment. ${ }^{64}$ The police were required to caution the suspect that he need not answer any questions but under section 3 of the Criminal Justice (Scotland) Act 1980 there was no right for the suspect to consult a lawyer before being questioned during this period, although the suspect was entitled to have intimation of his detention sent to a solicitor without unnecessary delay.

In Ireland Custody Regulations under the Criminal Justice Act 1984 required that all persons arrested and held in Garda custody were informed of their entitlement to consult a solicitor. ${ }^{65}$ Although the Irish courts adverted to the existence of a right of access to pre-trial legal advice in a number of cases dating back to the 1970s, the right did not gain constitutional status until 1990 when the Supreme Court gave constitutional recognition to the right of 'reasonable access' to a solicitor. ${ }^{66}$ The court did not specify the particular constitutional

60 See Royal Commission on Criminal Procedure, Report Cmnd 8092 (1981).

61 See Report of the Inquiry by the Hon Sir Henry Fisher into the Circumstances Leading to the Trial of Three Persons on Charges Arising out of the Death of Maxwell Confait and the Fire at 27 Doggett Road SE6 HC 90 (1977). The report considered that the then Judges' Rules should be amended to permit a solicitor to attend the interrogation if this is requested and the interrogation should be delayed until the solicitor arrives (ibid, para 2.22).

62 n 60 above, paras 4.89- 4.90.

63 ibid, para 4.88 .

64 Thomson Committee, Criminal Procedure in Scotland (Second Report) Cmnd 6218 (1975). The history to the background of the Thomson Committee's recommendations is recounted by Lord Rodger in his judgment in Cadder v HM Advocate [2010] 1 WLR 2601 at [74]-[86]. See Leverick, n 35 above; P. Duff, 'Chalmers to Cadder: Full Circle to Police Interrogation?' (2015) 19 Edinburgh Law Review 186.

65 Criminal Justice Act 1984 (Treatment of Persons in Custody in Garda Síochána Stations) Regulations 1987 , reg 8.

66 DPP v Healy [1990] ILRM 313. 
provision relied upon, however it appeared to recognise a two-fold raison d'être for the right: to inform the suspect of all his rights, including his right to silence, so that any decision to make a statement is freely reached and therefore voluntary and to redress the imbalance between the power and position of the suspect and that of the gardaí. ${ }^{67}$ A number of questions were left unanswered by the decision, not least what exactly was meant by 'reasonable' access. Clearly, however, the role of the solicitor was confined to one of giving advice and support and did not extend to the kind of active defence role required of counsel at trial.

In continental Europe there was a stronger cultural resistance to the notion that access to a lawyer was necessary to protect the suspect from any abuse or coercion during police questioning. The inquisitorial ideal presupposed that all questioning should be under the supervision of the investigating magistrate or prosecutors whose independent judicial status guaranteed due process. ${ }^{68}$ However, there were signs in the late twentieth century of some recognition of a right of access to a lawyer at some stage during police detention before trial, albeit the right was qualified and restricted in a number of jurisdictions. The criminal procedure codes in jurisdictions such as Germany, Spain and Italy aligned the right to be informed of the right of silence with the right to consult with a lawyer before interrogation. ${ }^{69}$ But other jurisdictions took a much more restrictive approach. In Belgium the lawyer only had a right of access after interrogation by the investigating judge. ${ }^{70}$ In The Netherlands access to a lawyer under the Code of Criminal Procedure of 1926 was qualified where in the opinion of the judge of instruction or prosecutor the interests of the investigation made the exercise of the right undesirable. ${ }^{71}$ In France suspects first obtained the right to request a meeting with a lawyer, lasting a maximum of 30 minutes, from the beginning of the garde à vue in 1993. But the exact point at which access should be granted and for how long became matters of much controversy in succeeding years. The law was repeatedly changed in the years leading up to the Salduz decision as successive governments of different political hues engaged in a game of 'political ping pong'. ${ }^{72}$

67 V. Conway, Y. Daly and J. Schweppe, Irish Criminal Justice: Theory, Process and Procedure (Dublin: Clarus, 2010) 53.

68 Hodgson, n 4 above, 347. Van Kessel reported in 1998 that 'there is no general understanding on the continent that a right to counsel during initial questioning of suspects by the police is a necessary aspect of a fair criminal process', n 28 above, 810 .

69 In Germany CCP, Art 163a(4) requires the police to inform suspects of their right to a lawyer before questioning. See also Spain CCP, Art 520 which permits the lawyer to be present during the interrogations. In Italy, under the reformed CPP of 1989, questioning of a suspect by the police cannot be conducted in the absence of a lawyer. In Germany the fact that the Code does not expressly grant the defence lawyer a right to be present has been interpreted as a denial of a right of attendance. See T. Weigend and F. Salditt, 'The Investigative Stage of the Criminal Process in Germany' in E. Cape, J. Hodgson, T. Prakken and T. Spronken (eds), Suspects in Europe (Antwerp: Intersentia, 2007) 79, 90.

70 J. Fermon, F. Verbruggen and A. De Decker, 'The Investigative Stage of the Criminal Process in Belgium' in Cape et al, ibid 29, 47.

71 Brants, n 45 above.

72 Giannoulopoulos, n 4 above, 299. See J. Hodgson, 'Constructing the Pre-trial Role of the Defence in French Criminal Procedure: French Criminal Justice' (2002) 6 IJEP 1, 39, S. Field and A. West, 'Dialogue and the Inquisitorial Tradition: French Defence Lawyers in the Pre-Trial Criminal Process' (2003) 14 Criminal Law Forum 261. Prior to Salduz suspects were limited to 
Even when access to a lawyer was granted in the continental procedures, the role of the lawyer was largely restricted to one of advising suspects of their rights, including the right of silence and did not extend to an active defence role of intervening in the interrogation and generally challenging evidence. ${ }^{73} \mathrm{It}$ is true that some of the reforms in France to increase access to defence counsel did spark debates which contested this limited conception of the defence role. ${ }^{74}$ But the dominant view of prosecutors and judges was that defence participation would interfere with effective investigation. ${ }^{75}$ Reforms in Spain arising from the requirement in the new Spanish Constitution of 1978 that arrested persons shall be guaranteed the assistance of a lawyer during police inquiries and judicial proceedings led to a debate about exactly what role lawyers should play in the police station. ${ }^{76}$ There were calls for lawyers to be able to intervene actively in all legal processes on behalf of the arrested person including during the interrogation of the accused. In the event, however, the role of the lawyer was limited to one of advising arrested persons of their rights and fell short of any active participation during the interrogation of the accused. ${ }^{77}$

\section{SALDUZ AND THE PRINCIPLE OF ACCESS TO A LAWYER}

It is against this background that the ECtHR issued its landmark decision in Salduz in 2008. Up to this point the ECtHR had followed many national jurisdictions by heavily qualifying the right of access to a lawyer, restricting it to certain circumstances and stating that it was subject to denial for good cause. In John Murray v United Kingdom ${ }^{78}$ the Court said that Article 6 will normally require that the accused be allowed to benefit from the assistance of a lawyer where national laws may attach consequences to the attitude of an accused at the initial stages of police interrogation which are decisive for the prospects of the defence in subsequent proceedings. The particular consequences in Murray related to the difficulties that arose from legislation permitting inferences to be drawn from an accused's silence and the need to be advised on whether to speak to the police. In Salduz ${ }^{79}$ the Court went much further by ruling that access to a lawyer should be provided as a rule from the first interrogation

30 minute meetings at the beginning of detention and then on each extension of detention which meant two 30 minute meetings within 48 hours of interrogation.

73 A. Dorange and S. Field, 'Reforming Defence Rights in French Police Custody: a coming together in Europe?' (2012) 16 IJEP 153, 156. cf, however, Germany where it appears that when defence counsel are present during the police questioning of a suspect, they may ask questions and make statements (personal correspondence with Thomas Weigend, 24 September 2015)

74 ibid.

75 For the view of prosecutors in France see Hodgson, n 4 above, 355-356.

76 H. W. McGee, 'Counsel for the Accused: Metamorphosis in Spanish Constitutional Rights' (1987) 25 Columbia Journal of Transnational Law 253, 278-279.

77 See CCP, Art 520.6. The government view was that the primary concern was to erase the spectre of physical abuse and to ensure that the defendant would not involuntarily answer questions. See McGee, ibid, 279-280.

78 (1996) 22 EHRR 29.

$79 \mathrm{n} 1$ above at [55]. 
of a suspect by the police unless it is demonstrated that there are compelling reasons to restrict this right. This may be described as the Salduz principle. In line with the recognition in certain national jurisdictions across the procedural traditions that a primary justification for access was to protect the accused's right of silence, reference was made to the particularly vulnerable position that the accused finds himself in at the investigation stage of the proceeding which in the majority of cases could only be compensated by the presence of lawyers. The right was expressly linked with the importance of preserving the privilege against self-incrimination when the court said that

early access to a lawyer is part of the procedural safeguards to which the Court will have particular regard when examining whether a procedure has extinguished the very essence of the privilege against self-incrimination. ${ }^{80}$

Although, as we shall see, the Court also adverted in its justification of the right to early access to a lawyer to other grounds than simply protecting the suspect from self-incrimination, it was the protective role that lawyers could play at this stage that was emphasised in national court decisions following the Salduz decision. Thus as Giannoulopoulos has illustrated in his article on custodial legal assistance in France, ${ }^{81}$ the Conseil constitutionnel and then the Cour de cassation took inspiration directly from Salduz. In the case before the Conseil constitutionnel ${ }^{82}$ the applicants highlighted the fact that under the existing legislation a person remanded in custody was entitled to speak with a lawyer for only 30 minutes, the lawyer involved had no access to the contents of the police file and could not be present during questioning and the person remanded in custody was not informed of his right to remain silent. In these circumstances it was argued that remanding a person in custody for police questioning failed to respect the rights of the defence. The court took the exceptional step of striking down the constitutionality of Article 63-4 of the Code of Criminal Procedure on the ground that it failed to allow a detainee to have the benefit of effective assistance of a lawyer while undergoing questioning and it failed to require the suspect to be informed of his right of silence. The court made an express link between the right to assistance and the right to silence, thus emphasising, as Salduz had done, the important protective role that lawyers can play. ${ }^{83}$ It chose not to refer, however, to the failure to acquaint the lawyer with the contents of the police file which would give the lawyer a basis on which to challenge the evidence against the accused. By the time of the later decisions of the Cour de cassation, the ECtHR had applied the Salduz ruling specifically against France in Brusco v France. ${ }^{84}$ The Cour de Cassation drew directly upon Salduz by holding that the requirements of Article 6 of the ECHR required that a suspect must not be questioned in the absence of his lawyer and that he must be informed of the right of silence and be assisted by a lawyer from the beginning of the garde à vue. ${ }^{85}$

80 ibid at [54].

81 Giannoulopoulos, $\mathrm{n} 4$ above.

82 Conseil constitutionnel, 30 juillet 2010, no.2010-14/22 QPC.

83 ibid at [28].

84 n 2 above.

85 Crim 19 Octobre 2010, Bull crim 163, 164, 165. 
The link between the right of silence, the privilege against self-incrimination and access to a lawyer was even more pronounced in the decision of the United Kingdom Supreme Court (UKSCt) in Cadder v HM Advocate ${ }^{86}$ (Cadder) to endorse Salduz rather than the approach of the Scottish courts, rejecting the Scottish system permitting the police to question suspects for six hours without allowing them access to a lawyer as unlawful. The High Court of Justiciary in HM Advocate v McLean ${ }^{87}$ had taken the view that it was unnecessary to provide access to a lawyer to a detainee if he or she were given sufficient other safeguards to secure a fair trial. The court stressed that the limited six hour apprehension on suspicion before charge to which the name 'detention' was given was subject to a number of safeguards, including a caution that the suspect need not answer questions; the tape recording of the subsequent interview; the inadmissibility of any statements obtained through coercion or other unfair means; a requirement that no adverse inferences may be drawn from silence; a requirement for any admission to be corroborated by independent evidence; and finally the fact that the detention may last for only six hours. ${ }^{88}$ To the Justices of the Supreme Court, however, these safeguards were 'beside the point' as the ECtHR had derived the suspect's right to legal advice specifically from the right against self-incrimination. ${ }^{89}$ Since, as Lord Rodger pointed out, this implied right was based on the need to protect the right of the person concerned not to incriminate himself, the only safeguards in Scots domestic law which could be relevant would be those designed to protect that right and the safeguards mentioned in HM Advocate v McClean although 'admirable' did not make up for the lack of any right for the suspect to take legal advice before being questioned as to whether he should say anything at all and, if so, how far he should go. ${ }^{90}$ The limited detention period allowed for questioning in the absence of legal advice was therefore the very converse of what the Grand Chamber had held was required by Article 6, namely a right of access to a lawyer before any questioning of a suspect has taken place in order to protect the suspect's right against self-incrimination.

The UKSCt accepted that the Grand Chamber judgment referred to other rationales for the right of access to a lawyer. Lord Hope referred to the reference in the judgment to the numerous recommendations by the European Committee for the Prevention of Torture and Inhuman or Degrading Treatment or Punishment which underlined the point that the right of any detainee to have access to legal advice is a fundamental safeguard against ill-treatment. ${ }^{91}$ In his Lordship's view, there was perhaps an indication here that the primary concern of the Grand Chamber was to eliminate the risk of ill-treatment or other forms of physical or psychological pressure as a means of coercing the detainee to incriminate himself. If this was the primary concern of the Grand Chamber then the use of techniques that were already evident in Scots law, such as the tape-recording of interviews, would meet

86 [2010] 1 WLR 2601.

87 [2009] HCJAC 97.

88 ibid at [27].

89 n 86 above at [66], [73] per Lord Rodger.

90 ibid at [92].

91 ibid at [33]. 
the need to monitor fairness. ${ }^{92}$ But Lord Hope considered that the way the Grand Chamber went on to express itself, and in particular its statement at the end of paragraph 55 that the rights of the defence will be irretrievably prejudiced when incriminating statements made during police interrogation without access to a lawyer are used for a conviction, showed that the emphasis throughout the Salduz judgment was on the presence of a lawyer as necessary to ensure respect for the right of the detainee not to incriminate himself. ${ }^{93}$ Later he pointed to the suggestion of the High Court of Justiciary that the Grand Chamber was particularly influenced by the ECtHR case of Jalloh v Germany ${ }^{94}$ where in contrast to the present case, a violation of Article 3 of the ECHR was also in issue. Lord Hope considered that the ECtHR plainly had in mind that:

there was a consensus across Europe that the presence of a lawyer was a safeguard against ill-treatment ... But it is just as plain that the risk of irretrievable prejudice to the accused because of a lack of respect of his right to remain silent was at the forefront of its mind too. ${ }^{95}$

The link between the right to legal advice and the privilege against selfincrimination was also very evident in the reasoning of the Irish Supreme Court ruling in $D P P$ v Gormley; $D P P$ v White $^{96}$ that a suspect has a right to early access to a lawyer after arrest and a right not to be interrogated without having had an opportunity to obtain legal advice. The Supreme Court went far beyond Strasbourg, taking in the jurisprudence of the supreme courts of the US, Canada, Australia and New Zealand, before reaching its conclusion that there was a 'clear international view to the effect that there is, at a minimum, an obligation in most circumstances (possibly subject to some exceptions) on investigating police to refrain from interrogating a suspect at a time after the suspect has requested a lawyer and before that lawyer has arrived to advise the suspect concerned'.$^{97}$ The court firmly grounded the right of access in the Irish constitutional entitlement to 'a trial in due course of law' stressing that once a suspect has been arrested and can be subjected to mandatory questioning, it is proper to regard the process as intimately linked with a criminal trial rather than being one at a purely investigative stage and that basic fairness of process must apply. ${ }^{98}$ This was the approach that the ECtHR and the USSCt had accepted. In an interesting comment on the difference between what fairness might entail before the trial as opposed to at trial, the court said that it did not follow that all of the rights which someone may have at trial apply at each stage of the process leading up to trial. However, the fundamental requirement of fairness applied from the time of arrest of a suspect so that any breach of that requirement can lead to an absence of a trial in due course of law. ${ }^{99}$ The court emphasised that the reasoning

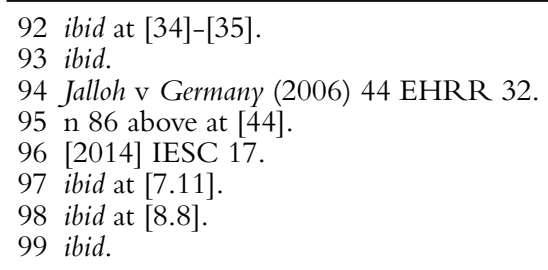


behind the obligation to ensure legal advice before questioning was to be found in the jurisprudence of courts whose judgments the Irish courts frequently regarded as persuasive. It referred in particular to Warren CJ's suggestion in Miranda as far back as 1966 that the right to have a lawyer present at the interrogation is indispensable to the protection of the privilege against selfincrimination, a proposition that applied equally to advice prior to interrogation. The court stressed that both the ECtHR in Salduz and the USSCt in Miranda had accepted that the entitlement not to self-incriminate incorporates an entitlement to legal advice in advance of mandatory questioning of a suspect in custody. ${ }^{100}$

It is interesting here that the Irish Supreme Court drew support for the principle of the right of access not only from the Salduz decision but also from the supreme courts of common law countries demonstrating the importance of considering the reasoning of courts with a similar procedural tradition. It has been pointed out that the Supreme Court's willingness to examine the jurisprudence of other common law courts is an excellent example of legal cosmopolitanism but it is cosmopolitanism from the angle of the common law. ${ }^{101}$ In this respect it falls short of the kind of cosmopolitan jurisprudence practised by the ECtHR which is directed at member states across the full spectrum of adversarial and inquisitorial traditions. There was no reference to simultaneous European attempts to apply the very same jurisprudence emanating from Strasbourg, nor any reference to the EU Directive to which Ireland had through its Presidency of the European Council secured agreement with the European Parliament, although it did not in fact opt into the Directive.

In the light of Salduz, then, courts in a number of countries came to accept the principle of a right of access to a lawyer when suspects are first questioned by the police but they did so in some instances after being assured that such a right was consistent with or even mandated by principles that had come to be accepted within their procedural tradition such as the privilege against self-incrimination. This is not to say that the principle of access to a lawyer before questioning would have been accepted without Salduz. Prior to Salduz, Belgium, France, Scotland, The Netherlands and Ireland had not recognised the principle. Since then, following decisions of their national courts, they have all introduced the right in some shape or form - in some cases by legislation; in other cases by prosecutorial decree. ${ }^{102}$ However, it does suggest

100 ibid at [9.13].

101 D. Giannoulopoulos, 'Strasbourg Jurisprudence, Law Reform and Comparative Law: A Tale of the Right to Custodial Legal Assistance in Five Countries' (2016) 16 HRLR 103.

102 Emergency legislation was introduced in Scotland to provide suspects with a right to legal advice before police questioning under the Criminal Procedure (Legal Assistance, Detention and Appeals)(Scotland) Act 2010. Legislation was introduced in France on 14 April 2011 and in Belgium on 13 August 2011. In The Netherlands and Ireland binding instructions have been issued by the prosecution service to give effect to the rule. See Brants, n 45 above, 302-303 and Y. Daly and J. Jackson, 'The Criminal Justice Process: from Questioning to Trial' in D. Healy, C. Hamilton, Y. Daly and M. Butler (eds), Routledge Handbook of Irish Criminology (Abingdon: Routledge, 2016) 292. See now Garda Code of Practice on Access to a Solicitor by Persons in Police Custody April 2015 at http://garda.ie/Documents/User/Code\%20of\%20Practice\% 20 on\%20Access\%20to\%20a\%20Solicitor\%20by\%20Persons\%20in\%20Garda\%20Custody.pdf (last accessed 29 July 2016). 
that unless Strasbourg - and by implication the other European institutions as well - can put forward a rationale for a procedural right which can be justified as coming within a broad domestic procedural tradition, it may not be able to secure the endorsement of member states for it. The lesson here for European institutions is that in trying to command consensus on procedural rights, they must be able to communicate with the procedural traditions of member states as these traditions can be influential in determining whether the rights will be accepted. It is not enough for the court to provide a rationale purely in terms of 'Strasbourg' jurisprudence, what has been described as a 'court-centred' explanation of acceptance of ECtHR jurisprudence. ${ }^{103}$ 'Court-centred' explanations have to be considered together with 'member state-centred' explanations that offer an account of acceptance in terms of indigenous traditions and other forces shaping national responses. This can be illustrated further when we look beyond the principle of the right of access at how the right has been applied in the member states and in particular at the kind of role that lawyers are permitted to play when they have been granted access.

\section{DEFENCE ROLES DURING POLICE INVESTIGATION}

Although Salduz firmly established the principle of early access to a lawyer, it said little about what kind of access was required and what kind of legal assistance should be given to suspects once access is granted. We have seen that Salduz grounded the right to early access to a lawyer primarily in the privilege against self-incrimination but this still leaves considerable scope for argument as to what kind of access this entails. One of the difficulties lies in determining what exactly the privilege against self-incrimination is designed to achieve. Although the privilege is a widely accepted principle, scholars have struggled to find a convincing rationale that justifies it as a self-standing right that should exist over and above the absolute right not to be subjected to torture, inhuman or degrading treatment and the more qualified, general right to privacy that all persons, not just suspects, are entitled to. ${ }^{104}$ When construed narrowly as a right not to be compelled to make a confession, the right seems barely distinguishable from a right not to be subjected to physical or psychological ill-treatment. On this view, access to a lawyer is only necessary to guard against foul play and it has been pointed out that other safeguards such as those mentioned in HM Advocate v McLean are just as efficacious in doing this. ${ }^{105}$ When the privilege is associated more broadly with respecting the will of the

103 Giannoulopoulos, n 101 above. cf J. Jackson and S. Summers, 'Confrontation with Strasbourg: UK and Swiss Approaches to Criminal Evidence' [2013] Crim LR 114.

104 See the discussion in A. Zuckerman and P. Roberts, Criminal Evidence (Oxford: OUP, $2^{\text {nd }}$ ed, 2010) 547-563; I. H. Dennis, 'Instrumental Protection, Human Right or Functional Necessity: Reassessing the Privilege against Self-Incrimination' (1995) 54 CLJ 342; S. Easton, The Case for the Right of Silence (Vermont: Ashgate, $2^{\text {nd }}$ ed, 1998); M. Redmayne, 'Rethinking the Privilege against Self-Incrimination' (2007) 27 OJLS 209; J. Jackson, 'Re-Conceptualising the Right of Silence as an Effective Fair Trial Standard' (2009) 58 ICLQ 835.

105 P. Ferguson, 'Repercussions of the Cadder Case: the ECHR's Fair Trial Provisions and Scottish Criminal Procedure' [2011] Crim LR 743, 751. 
accused when he or she decides not to cooperate with a criminal investigation, however, it is difficult to see why it should always prevail over the state's interest in obtaining information from suspects when there is evidence linking them to an offence, provided this is acquired under appropriate conditions of procedural fairness. Access to a lawyer arguably constitutes one of the conditions of procedural fairness that should be met before inferences can be drawn against any refusal by a suspect to answer questions, as the ECtHR ruled in Murray, but this suggests that access is more properly founded on the need to obtain advice on how to respond to accusations against one than upon any a priori need to uphold the privilege against self-incrimination.

The scope of the privilege also affects the kind of access that should be granted. The ECtHR has struggled to explain why if the privilege is founded on respect for the accused's will, it should not be extended to situations where suspects are required to hand over documents or to submit to the taking of breath, blood and urine samples and bodily tissues for the purpose of DNA testing. ${ }^{106}$ We have seen that the USSCt in Miranda strongly affirmed the need for the lawyer's presence during any custodial questioning if the privilege was to be properly protected. But, arguably, the risk to the suspect's privilege against self-incrimination can be triggered when he or she is subjected to any questioning by a person in authority whether in custody or not, or indeed, more broadly, to any state action designed to obtain material that may be incriminating. This would seem to point to the need for a lawyer being present at every stage where information or material is sought by the state. But this has not been required by Strasbourg.

Other jurisdictions which have accepted the principle of early access to a lawyer have not even endorsed the implication that this requires a lawyer's presence during a suspect's questioning at any stage. In its interpretation of section 10(b) of the Canadian Charter of Rights and Freedoms which states that upon arrest or detention, a person has a right to 'retain and instruct counsel without delay', the majority of the Canadian Supreme Court in $R$ v Sinclair ${ }^{107}$ considered that the purpose is to provide the detainee with an opportunity to obtain legal advice relevant to his legal situation and in the context of a custodial interrogation. Chief among the rights that must be understood by the detainee is the right under section 7 of the Charter to choose whether to cooperate with the police or not. The legal advice that this entailed required that the detainee be told of the right of silence and how to exercise the right in the situation in which the detainee was placed but, importantly, the court did not consider that this went so far as advising the detainee on how to deal with police questions. ${ }^{108}$ The purpose of the right was informational rather than protective. This meant a right to consult counsel to obtain information and advice immediately upon detention but it did not entail extending this to providing ongoing legal assistance during the course of the interview, regardless of the circumstances, and did not entail any right to have counsel present during the interview. It was

106 See J. D. Jackson and S. J. Summers, The Internationalisation of Criminal Evidence (Cambridge: CUP, 2012) 268-270. cf Redmayne, n 104 above.

107 [2010] SCC 35, SCR 310 at [24].

108 ibid at [31]. 
accepted that there could be a second consultation but only where there was a material change in the detainee's situation after the initial consultation.

One of the minority Justices in Sinclair considered that in order to give advice on how to exercise the right of silence, there was a need for the lawyer to be aware in at least a general way of the unfolding case being put to his client and this meant that the detainee should be given reasonable access to legal advice from time to time in the course of police interrogation. ${ }^{109}$ The other minority Justices went further and took the view that the detainee should have unfettered access to his lawyer during interrogation because the purpose of section 10 was not merely to advise the client on the exercise of the right of silence but to protect the detainee's exercise of the right. But even the dissentients did not consider that this necessarily entailed the presence of counsel during interview. ${ }^{110}$

There is clear language in the judgment of the Grand Chamber in Salduz that the purpose of access to a lawyer extends to protecting the exercise of the privilege against self-incrimination. The ECtHR emphasised the particularly vulnerable position of the accused at the investigation stage and stressed that the vulnerability of the accused can only be compensated by the assistance of a lawyer whose task it is, among other things, to help ensure respect for the right of an accused not to incriminate himself. ${ }^{111}$ This emphasis on respecting the right against self-incrimination suggests that the lawyer has a role to ensure the right is enjoyed and not merely properly understood and the reference to ensuring that evidence is not obtained through methods of coercion or oppression underlines this protective role. This is reflected in later jurisprudence where the ECtHR emphasised the importance of legal assistance being available 'when' an applicant is being questioned. ${ }^{112}$ It has now been put beyond doubt that legal assistance requires the presence of a defence lawyer during custodial questioning. ${ }^{113}$

Although this would seem to be a clear affirmation of the protective role that lawyers should play in the police station, there are also signs in the jurisprudence that the ECtHR envisages lawyers playing a broader role than simply one of protecting the accused's rights. In Salduz itself the court referred to the importance of preventing miscarriages of justice and fulfilling the aims of Article 6, notably the equality of arms between investigating or prosecuting authorities and the accused. ${ }^{114}$ The court went on to underline the importance of the investigation stage for the preparation of the criminal proceedings, as the evidence obtained during this stage determines the framework in which the offence charged will be considered at trial. ${ }^{115}$ At the same time, it said, an accused often finds himself in a particularly vulnerable position at this stage which is amplified by the fact that legislation on criminal procedure tends to become increasingly complex, notably with respect to rules

109 ibid at [76]-[122] per Binnie J.

110 ibid at [123]-[226] per Lebel and Fish JJ.

$111 \mathrm{n} 1$ above at [54].

112 See, for example, Panovits v Cyprus n 2 above at [66], Brusco v France $\mathrm{n} 2$ above at [54].

113 See, for example, Mader v Croatia ECtHR 21 June 2011, Sebalj v Croatia ECtHR 21 June 2011.

114 (2009) 49 EHRR 421 at [53].

115 ibid at [54]. 
governing the gathering and use of evidence. ${ }^{116}$ Here, the court appears to be emphasising not only the protective role that the lawyer can play in ensuring that detained persons are not coerced into making confessions but also the more representational role that is required in advising on the complexities of the case against the accused and gathering and using evidence.

This role is emphasised particularly in the concurring opinions of Judges Zagrebelsky and Bratza who would have preferred the ECtHR to have held that detained persons should be entitled to access to legal assistance not just from the point of interrogation but as soon as they are imprisoned so that from that stage they can give their lawyer instructions in order to prepare their defence. This broader role is one that was explicitly endorsed in Dayanan v Turkey ${ }^{117}$ where the applicant complained that he had had no legal assistance while he was in police custody. The government argued that because the applicant had exercised his right of silence under questioning in police custody, the absence of a lawyer had in no way affected the observance of his defence rights. In response to this argument the ECtHR declared that a suspect should be granted access to legal assistance from the moment he is taken into custody or pre-trial detention, adding that:

the fairness of proceedings requires that an accused be able to obtain the whole range of services specifically associated with legal assistance. In this regard, counsel has to be able to secure without restriction the fundamental aspects of that person's defence: discussion of the case, organisation of the defence, collection of evidence favourable to the accused, preparation for questioning, support of an accused in distress and checking of the conditions of detention. ${ }^{118}$

Although this passage sets out a broader vision of the defence role, there has been little subsequent Strasbourg jurisprudence fleshing out its implications. The issues that have come before the ECtHR have tended to focus upon the refusal to grant any meaningful access to a lawyer in direct breach of the Salduz principle rather than upon the particular role that the lawyer has been able to play once access is granted. ${ }^{119}$ National courts have in turn been remarkably cautious about promoting any active role of the kind envisaged in Dayanan. There would seem to be two reasons for this. First of all, national courts have traditionally stuck to the letter of the Strasbourg jurisprudence. We have seen that the ECtHR did not at first specify that the access that should be provided as from the first interrogation of a suspect by the police required the presence of a lawyer during the interrogation. In its ruling in a case where a minor in police custody had made statements without the assistance of a lawyer which were used in evidence against him, the Dutch Supreme Court held that neither Salduz nor Panovits v Turkey (a case involving a minor) implied a general right

116 ibid.

117 n 2 above.

118 ibid at [32].

119 See, however, Aras v Turkey (no 2) ECtHR 18 Nov 2014, holding that the purely 'passive presence' of a lawyer in the hearing room during the questioning of the applicant with no possibility to consult the applicant or to intervene to ensure respect for the applicant's rights did not satisfy the Salduz requirement of access to a lawyer. 
to have a lawyer present during the interrogation, although it accepted that minors were an exception. ${ }^{120}$ The court only recently ruled that lawyers have the right to be present in all cases, as of 1 March 2016 ${ }^{121}$ By the time the French Cour de cassation came to give its rulings, the ECtHR had already ruled in Brusco $\mathrm{v}$ France that a person subjected to a garde à vue 'has the right to be assisted by a lawyer from the beginning of this measure as well during questioning' and the judgments reflected the requirement that the suspect must not be questioned in the absence of his lawyer. We have seen that the Irish Supreme Court drew on other jurisprudence to elicit the principle that questioning should not proceed after a suspect has requested a lawyer but it was cautious about going beyond the facts of the cases before it to find a right to be present during questioning. The court rejected a separate appeal based on a claim that where a person is in custody and has requested a solicitor, the police were obliged not to take any forensic samples until such time as legal advice has been received. Although the court considered that under Irish constitutional law it might be different where the suspect has genuine legal choices available in respect of the taking of samples, in this case the suspect had no legal choice other than to comply and the court's treatment of the issue was limited to a consideration of whether the taking of objective forensic samples without the benefit of legal advice amounted to a breach of the right against self-incrimination. The court said not.

Even domestic courts such as the UKSCt, which have appeared favourably inclined towards accepting the Salduz principle have done so on the basis that there is 'clear and constant' Strasbourg jurisprudence for it and have considered that it is outside their remit to develop the principle further than Strasbourg has gone. ${ }^{122}$ This approach was summed up in the dictum of Lord Bingham in $R$ (Ullah) v Special Adjudicator, ${ }^{123}$ that the duty of national courts is to keep pace with the Strasbourg jurisprudence as it evolves over time: 'no more, but certainly no less', which was later given a 'characteristically stylish twist' by Lord Brown in $R$ (Al-Skeini and others) v Secretary of State for Defence ${ }^{124}$ where he said that the sentence could 'as well have ended: no less, but certainly no more'.

This cautious approach is reflected in later post-Cadder jurisprudence. ${ }^{125}$ Thus in Ambrose v Harris ${ }^{126}$ (Ambrose) the accused was questioned at the

120 HR, 30 June 2009, LJN BH3084. See Brants, n 45 above. A number of jurisdictions now accept that the right to legal assistance for juvenile suspects includes the right to have a lawyer present during the interrogation. See M. Panzavolta, D. De Vocht, M. van Oosterhout and M. Vanderhallen (eds), Interrogating Young Suspects: Procedural Safeguards from a Legal Perspective (Antwerp: Intersentia, 2015).

121 HR, 22 Dec 2015, NJ 2016/52.

122 According to Lord Hope in Cadder, n 86 above at [47], the Strasbourg case law showed that Salduz had been followed repeatedly in subsequent cases. Although they did not need to rule upon the question, the Justices in Cadder did not venture an opinion on whether a solicitor needed to be present throughout the interview and the emergency legislation that was passed in Scotland in response to Cadder failed to make it clear whether this was required.

123 [2004] 2 AC 323 at [20].

124 [2008] 1 AC 153 at [106]. Lord Kerr described this as a 'characteristically stylish twist' in Ambrose v Harris (Procurator Fiscal) [2011] 1 WLR 2435 at [126].

125 See R. M. White and P. Ferguson, 'Sins of the Father: The "Sons of Cadder"' [2012] Crim LR 357.

126 [2011] 1 WLR 2435. 
roadside by police and, although cautioned that he need not reply to questions, made admissions without legal advice about driving when he was under the influence of alcohol. The majority judgment engaged in an extensive review of the Strasbourg authorities to reach the conclusion that it would be to go further than Strasbourg had gone to hold that his right of access had been breached. In the majority's view, the ECtHR had not said, or at least had not said with sufficient clarity, that a person who has become a suspect and is not in custody must as a rule have access to a lawyer. ${ }^{127}$ The same kind of reasoning was used in $M c$ Gowan $v B^{128}$ to reject the argument that any valid waiver of the Salduz right required the suspect first to receive legal advice before deciding whether to exercise the right. According to the Justices, there was no rule to this effect that had been identified by the Strasbourg court. The task of the court was primarily by examination of Strasbourg jurisprudence to identify as best it could the requirements which the Strasbourg Court had set for waivers to be effective. $^{129}$

Apart from a natural reluctance to go beyond a 'clear and constant' jurisprudence from Strasbourg in developing the Salduz principle, it would seem that there has also been no inclination on the part of national courts and legislatures to extend the principle beyond the rationale of self-incrimination that was used to justify the original Salduz decision. In Ambrose heavy reliance was placed - as it was in Cadder - on the principle against self-incrimination as the rationale for the exercise of the right of access to a lawyer. But this time it was used to narrow the scope of the Salduz principle. Although we have seen that the privilege against self-incrimination might be considered at risk in any situation where a suspect is subjected to questioning by a person in authority, the majority judgments considered that the 'paradigm' case where a suspect was at risk of a forced confession was when he was in custody or when his freedom of action has been significantly curtailed. ${ }^{130}$ The decision to confine access to when a suspect might be most at risk of making a coerced confession betrays a narrow application of the privilege against self-incrimination in its own terms and a distinct aversion towards contemplating some of the broader rationales for the principle of access which led the ECtHR to contemplate a wider role for lawyers than simply protecting the privilege.

When one reviews the various national laws and provisions that have been introduced by member states in the aftermath of Salduz and the decisions of national courts, they by and large accede to the principle of early lawyer access and presence during police questioning but stop short of envisaging any active role for lawyers. Thus in France and Belgium lawyers are restricted to exercising a passive non-adversarial role during questioning, which prohibits them from asking questions or entering into discussions with the police during the interview. ${ }^{131}$ In a decision given on 18 November 2011 the French Conseil

127 ibid at [64] per Lord Hope. See also at [82] per Lord Brown and at [95] per Lord Dyson.

128 [2011] 1 WLR 3121.

129 ibid at [5] per Lord Hope, at [78] per Lord Hamilton.

130 n 126 above at [57] per Lord Hope.

131 See the French CCP, Art 63-4-3 inserted by the Law of April 2011 Art 8 and in Belgium Circulaire n 8/2011 du College des procureurs généraux près les Cours d'appel, 23 Nov 2011, at 52 . 
constitutionnel specifically held that the Law of April $14^{\text {th }}$ did not require that lawyers should be given access to the case file or be able to enter into any débat contradictoire during the garde à vue. ${ }^{132}$ A bill currently pending before the Dutch Parliament finally makes provision for the presence of lawyers during police questioning in The Netherlands but lawyers are restricted to a passive, non-adversarial role limiting any questions from the lawyer to the beginning and end of the police interview. ${ }^{133}$ Common law jurisdictions have been less prescriptive but here also there is no expectation that lawyers will play an active adversarial role. The lawyer's role in the police station in Scotland and Ireland has yet to bed down. In England and Wales, where the right of access has been in existence for many years since the enactment of PACE in 1984, the Code of Practice permits lawyers in an interrogation, to 'seek clarification, challenge an improper question to their client or the manner in which it is put, advise their client not to reply to particular questions or if they wish to give their client further legal advice'. ${ }^{134}$ But this falls short of giving lawyers any full-blooded adversarial role that is reserved for the trial process. Lawyers generally have no right to participate in an investigation, no right to be present at police interviews of witnesses and very limited disclosure of the case against their client. ${ }^{135}$ Their role is summed up in the Code as one of 'only' protecting and advancing the legal rights of their client. ${ }^{136}$ Even in the US which has the reputation of facilitating the most aggressive kind of active defence participation at trial, the role of lawyers when suspects are to be questioned is confined to advising them on their Miranda rights rather than engaging in any active manner with the case that is put against their clients. ${ }^{137}$

We can conclude from this that although both traditions have come to accept the principle of early lawyer access, albeit in the case of some countries immersed in the inquisitorial tradition with extreme reluctance, neither tradition has accepted the idea that an active defence should be conducted at the stage of police investigation. Both traditions have considered that the trigger for active defence participation is more properly activated after the police investigation when the case is ready for 'adversarial' argument. In the adversarial model this stage does not begin until formal charges are brought and court proceedings are under way. In the inquisitorial model it only begins when the investigating judge or prosecutor becomes active in the case. In a recent study carried out across both traditions in England, Scotland, France

132 Décision 2011-191/194/195/196/197-QPC of 18 Nov 2011. See Giannoulopoulos, n 4 above, 324, Blackstock et al, n 6 above, 91.

133 See C. Brants, 'What Limits to Harmonising Justice?' in Colson and Field, n 8 above.

134 Home Office, Revised Code of Practice for the Detention, Treatment and Questioning of Persons by Police Officers; Police and Criminal Evidence Act 1984 (PACE) - Code C, Note 6D, May 2014.

135 The Code has recently been amended to provide that persons interviewed be given sufficient information to enable them to understand the nature of the suspected offence and why they are suspected of committing it in line with EU Directive 2012/13/EU on the right to information in criminal proceedings, OJ L 142/1. See E. Cape, 'Transposing the EU Directive on the Right to Information: A Firecracker or a Damp Squib?' [2015] Crim LR 48.

136 PACE Code C, n 134 above, Note 6D.

137 See Van Kessel, n 41 above, 837-838. 
and The Netherlands, lawyers most commonly characterised their role in the police station as ensuring that procedures were followed and that suspects were properly treated. ${ }^{138}$ Although there were variations across countries in the degree to which lawyers were prepared to engage in a more active defence role, with the spectrum of practices varying according to how 'adversarial' or 'inquisitorial' their criminal justice systems are, it was rare for lawyers in any system to perform the whole range of functions associated with legal assistance identified by the ECtHR in Dayanan v Turkey.

It is true that the EU Directive on Access to a Lawyer, which is due now to be implemented in a number of member states, does appear to contemplate a somewhat more active role for lawyers in the police station than simply passive attendance. ${ }^{139}$ The Directive spells out certain aspects of the lawyer's role in more detail than the Strasbourg jurisprudence. For instance, instead of simply stating, as Salduz did, that suspects shall have access to a lawyer 'from the first interrogation', the Directive states in clear terms that this includes a right to 'meet in private and communicate with the lawyer representing them, including prior to questioning by the police'. ${ }^{140}$ In a recent decision the court took account of this provision in confirming that access to a lawyer includes a right to consult with that lawyer privately before any questioning takes place. ${ }^{141}$ The use of EU law can help the ECtHR rely upon a progressive interpretation of the ECHR to advance its vision of an active role for the defence. ${ }^{142}$ However, there are limits to the extent to which signatories of the Directive were prepared to advance this vision. For example, the Directive states that member states should ensure that suspects or accused persons have the right for their lawyer to 'be present and participate effectively when questioned'. ${ }^{143}$ But it then goes on to provide that such participation 'shall be in accordance with procedures in national law', adding somewhat ambiguously 'provided such procedures do not prejudice the effective exercise and essence of the right concerned'. ${ }^{144}$ The original proposal of the European Commission was much less ambiguous, envisaging that the lawyer would play an active role during police questioning with a 'right to ask questions, request clarification and make statements'. ${ }^{145}$

138 Blackstock et al, n 6 above, 337. See also J. Hodgson, 'From the Domestic to the European: an empirical approach to comparative custodial legal advice' in J. Ross and S. Thaman (eds), Research Handbook on Comparative Criminal Procedure (Cheltenham: Edward Elgar, 2015).

139 n 8 above.

140 ibid, Art 3(3)(a).

141 AT v Luxembourg ECtHR 9 April 2015.

142 See also Zachar and Cierny v Slovakia ECtHR 21 July 2015, where the ECtHR acknowledged the relevance of the EU Directives on the Right to Information and on the Right to Access to a Lawyer before ruling that the applicants who were told they were suspected of trafficking in drugs should have been informed of the more serious aggravated offences hanging over them before they agreed to waive their right of access to a lawyer.

143 n 8 above, Art 3(3)(b).

144 ibid.

145 Proposal for a Directive of the European Parliament and Council on the right of access to a lawyer in criminal proceedings and on the right to communicate upon arrest, Brussels, 8.6.2011 COM (2011) 326, art 4. 


\section{CONCLUSION: TOWARDS AN ACTIVE DEFENCE AT THE INVESTIGATION STAGE?}

Much has been said about the dialogic relationship between the ECtHR and national courts. ${ }^{146}$ The Salduz experience suggests that the ECtHR can win acceptance for its approach when there is a 'clear and constant' jurisprudence to support it and it is able to appeal to principles that cohere with procedural traditions. The principle of access to a lawyer prior to and during police questioning of suspects has been the subject of clear and constant jurisprudence and has been accepted by national courts because it has been able to appeal to the need to respect the well-established privilege against self-incrimination. However, the principle has not been applied by national courts as expansively as the ECtHR has envisaged and this suggests that there are certain limits to the cosmopolitan jurisprudence of the Strasbourg court so far as national courts are concerned. In particular, we have seen that there has been a reluctance to go beyond any clear and constant jurisprudence emanating from Strasbourg and to develop the jurisprudence beyond the boundaries set by domestic law.

This cautious attitude towards the Strasbourg jurisprudence can be challenged. It is true that the role of the ECtHR differs from that of national courts. The ECtHR's primary role is not to defer to procedural tradition but to set out principles that it believes are required under the Convention, recognising however that the Convention is built upon values that are widely shared across the procedural traditions and indeed underlie these traditions. The national courts for their part should not have to defer to the Strasbourg principles where they are perceived to deviate too far from procedural tradition. ${ }^{147}$ But where the principles that are developed are underpinned by shared values, national courts should strive to integrate them as far as possible within their procedural tradition. Instead of seeing 'Strasbourg' principles as 'belonging' to Strasbourg and unable to extend to situations which have not yet been considered by Strasbourg, this would seem to require that where possible they should be interpreted as domestic principles to be developed in line with the way principles emanating from within domestic procedural traditions are applied. Irrespective, then, of the extent to which national courts are bound to apply the ECtHR's jurisprudence as a matter of national law, this jurisprudence should not be seen as 'foreign' to the procedural tradition of member states.

146 See, for example, Dialogue between Judges (Strasbourg: European Court of Human Rights, 2012); Lord Kerr, 'The Conversation between Strasbourg and National Courts - Dialogue or Dictation?' (2009) 44 Irish Jurist 1; 'The UK Supreme Court - The Modest Underworker of Strasbourg?' Clifford Chance Lecture 25 January 2012 at https://www.supremecourt.uk/docs/speech_120125.pdf (last accessed 25 May 2016).

147 See, for example, the UKSCt's rejection of the confrontation principle developed by Strasbourg in R v Horncastle [2009] 2 AC 373 at [107], Lord Phillips emphasising that the jurisprudence of the ECtHR in relation to ECHR, Art 6(3)(d) developed largely in cases relating to civil law rather than common law jurisdictions without full consideration of the safeguards against an unfair trial that existed under common law procedure. See Jackson and Summers, n 103 above. 
It has been suggested in the UK context that there has been a tendency for Convention rights to be interpreted as a discrete body of domestic law derived from the judgments of the ECtHR rather than as a basis for the development of domestic law when it fails to meet the standards applied. ${ }^{148}$ If, however, principles developed by the Strasbourg court are accepted as rooted in domestic tradition, then they can be regarded as already domesticated and it can be argued that national courts should develop them in this spirit. This would appear to be the position of Lord Kerr, the dissenting judge in the UKSCt decisions of Ambrose and McGowan mentioned above, when he said that the domestic court could not simply wait until Strasbourg had pointed the way. The domestic court had a duty not only to ascertain where the jurisprudence of the Strasbourg court clearly shows that it currently stands but to resolve the question of whether the claim to a Convention right is viable or not, even where the Strasbourg jurisprudence has not yet disclosed a clear view: ${ }^{149}$

If the much vaunted dialogue between national courts and Strasbourg is to mean anything, we should surely not feel inhibited from saying what we believe Strasbourg ought to find in relation to those arguments. ${ }^{150}$

We have seen that the ECtHR has underpinned the Salduz principle by reference to the need to respect a number of principles that are shared across different procedural traditions, not just the privilege against self-incrimination but, in addition, the need to avoid miscarriages of justice and respect the equality of arms. The approach of national courts should then be to develop the principle of access to a lawyer not just as an 'add on' to domestic tradition but as contributing to its core aims as well as the aims of Article 6 of the ECHR. This is the way that the minority judges in Sinclair approached the equivalent right of access to a lawyer in Canada under section 10(b) of the Charter. The dissentients agreed with the majority view that the 'over-arching purpose' of the right to counsel lay in the protection against compelled self-incrimination which in turn preserved 'fairness' in the investigative process but considered that the role of counsel in the administration of justice and under section 10(b) of the Charter was 'much broader'. ${ }^{151}$ Their view was shaped by what they saw as the role of counsel within the justice system generally - to ensure the proper administration of justice by giving effective assistance during the all important pre-charge phases when what occurs will likely influence the nature of the proceedings that follow. ${ }^{152}$ This reflects the view that the Charter right under section 10 (b) is not some 'add on' to existing rights but is firmly embedded in the 'right granted to every accused by the common law, the

148 Lord Reed, 'Human Rights and Domestic Legal Traditions' in R. G. Anderson, J. Chalmers and J. MacLeod (eds), Glasgow Tercentenary Essays: 300 Years of the School of Law (Edinburgh: Avizandum, 2014) 164, 174.

149 n 126 above at [129].

150 ibid at [130].

151 n 107 above at [161].

152 ibid at [161]-[165]. 
Criminal Code and sections 7 and 11(d) of the Charter to be given the effective assistance of counsel . . . as a principle of fundamental justice'. 153

The Salduz principle should arguably be developed in a similar way by national courts. We have seen that there would appear to be a reluctance to develop the principle specifically in the direction of giving lawyers a more active role in assisting suspects under investigation. But as we have seen when we reviewed the introduction of defence counsel into the trial phase, traditions themselves evolve to meet the demands of truth finding and fairness as circumstances change. Just as the introduction of prosecutors in the criminal trial led to a need for a defence role to counter-balance that of the prosecution in order to secure a just outcome, so the dominance of the police in the investigation phase arguably requires an active defence at this stage as well when the product of investigation crucially affects the outcome of the proceedings. In his dissenting judgment in Ambrose Lord Kerr pursued an openly teleological approach towards the Salduz right by asking what its purpose was. His Lordship agreed with the respondent's argument that the right should not be viewed solely as a measure for the protection of the individual's interests. ${ }^{154}$ It was in the interests of society as a whole that those whose guilt or innocence may be determined by reference to admissions made in moments of vulnerability are sufficiently protected so as to sustain confidence in the reliability of those confessions. More broadly, Lord Kerr drew from Strasbourg jurisprudence the general conclusion that where an aspect of the proceedings which may be crucial to their outcome is taking place, there is a need for an effective defence by a lawyer. ${ }^{155}$ The investigation stage was important because the evidence obtained at that stage determines the framework in which the offence charged will be considered at trial and because it was at that very time when the accused himself is in a vulnerable position. Lord Kerr did not equate vulnerability here simply with being in custody:

$\mathrm{He}$ is vulnerable because at this investigation stage, evidence which may be instrumental in securing a finding of guilt against him is being obtained and collated. The way that he reacts during the collection of that evidence may prove to be of critical importance in his subsequent trial. ${ }^{156}$

It was not the place at which admissions are made nor whether the individual making the statement is in detention that was important but the use to which such statements may subsequently be put at trial. ${ }^{157}$

As in the Sinclair minority judgments, we see here the beginnings of the development of a role for counsel which can be equated to their role at trial, not just to protect the accused's personal interest but to ensure that an effective defence is put in the interests of the administration of justice as a whole. The need for an effective defence may have been traditionally established only at trial, but as criminal procedure has developed to include what the minority in

153 ibid at [168] (emphasis in original).

$154 \mathrm{n} 126$ above at [132].

155 ibid at [135].

156 ibid at [137] (emphasis in original).

157 ibid at [138]. 
Sinclair referred to as 'skilled and persistent' interrogation at the investigation stage where an accused's response to police questions may have critical consequences for the trial, fairness dictates that he or she needs a lawyer to advise on the legal issues that bear directly on the defence much in the way that a lawyer would advise an accused before evidence is given in court. ${ }^{158}$ The need to provide an effective defence at the stage of police questioning provides a better justification for the lawyer's presence than any need to protect the suspect's right against self-incrimination. We have seen that suspects can be protected against any compelled incrimination by other means. In so far as the privilege protects suspects from speaking at all, it can be argued that silence is only one of many options which need to be considered in deciding how to respond to police questioning and the lawyer's presence is required to advise on the full range of options in the light of the consequences that may attach in subsequent criminal proceedings to the suspect's attitude during questioning. The suspect's understanding of the ways in which the absence of a lawyer at the stage of police questioning might have an impact on the viability of his defence should similarly govern what constitutes an effective waiver of the right of access rather than simply any need to protect the suspect from coercion of his will. ${ }^{159}$ Whether suspects should have a right of access to a lawyer at other evidence-gathering events during the investigation would seem to depend on whether suspects have legal choices to make at these events which may bear on their defence.

There is, however, a further respect in which a lawyer may be needed to play an active role in the investigation phase. The ECtHR in Salduz signalled the important impact which this phase may have for the trial but the reality is that increasing numbers of cases in many jurisdictions do not reach trial at all. As legal systems across the procedural traditions have come to embrace notions of managerialism, ${ }^{160}$ there have been moves to try to dispose of cases in the early stages of proceedings, well before they reach trial. Increasingly in common law jurisdictions, incentives are being given to suspects to admit their guilt promptly. In order to secure the full sentence discount in England and Wales, a defendant has to plead guilty at the 'first reasonable opportunity', which can encompass statements made in the police station. ${ }^{161}$ Increasing numbers of cases are also diverted away from the court through the use of cautions which are an alternative to prosecution in return for an admission of guilt and which form part of a defendant's criminal record. ${ }^{162}$ A system of conditional cautions has also been put in place under which prosecutors agree not to prosecute persons who have admitted guilt and are prepared to

158 This would seem to equate to the 'critical stage' test that the USSCt has used to determine when the right to counsel is triggered in US law. See Coleman v Alabama (1970) 399 US 1. I am indebted to Máximo Langer for drawing my attention to this.

159 See also Lord Kerr's dissenting judgment in McGovern v B [2011] 1 WLR 3121 at [108].

160 See, for example, J. McEwan, 'From Adversarialism to Managerialism: criminal justice in transition' (2011) 31 Legal Studies 519; R. Colson and S. Field, The Transformation of Criminal Justice: Comparing France with England and Wales (Paris: L'Harmattan, Bibliothèques de droit, 2011).

161 See Sentencing Guidelines Council, Reduction in Sentence for a Guilty Plea (2004).

162 See Ministry of Justice, Simple Cautions for Adult Offenders (2013). Cautions were replaced for young defendants by a system of reprimands and final warnings under the Crime and Disorder Act 1998. 
comply with certain conditions as an alternative to prosecution. ${ }^{163}$ Civil law systems have also adopted procedures equivalent to guilty pleas or systems of informal sanctions. ${ }^{164}$ The German Code of Criminal Procedure provides for case resolution whereby the court gives an indication of a more lenient sentence in exchange for the defendant's confession. ${ }^{165}$ France and Italy have likewise developed equivalents to plea bargaining, known as the comparution sur reconnaissance préalable de culpabilité in France and the patteggiamento in Italy. ${ }^{166}$

The increasing pressure for cases to be disposed of without trial makes the role of the defence at the investigation phase before the trial all the more important. Formal sentence after trial is being replaced by a negotiated sentence or sanction after investigation, so that the investigation phase effectively becomes the trial. If the investigatory phase is being transformed in many cases into the accusatory phase of the trial, then it must follow that the procedural safeguards that have traditionally been considered necessary for the legitimacy of the trial need to be frontloaded on to the investigatory phase. The Salduz principle becomes in consequence not only necessary in order to ensure that the suspect is advised about his rights and to ensure that they are respected; it also becomes necessary to ensure compliance with the principles of equality of arms and adversarial procedure that have traditionally been reserved for the trial phase.

These developments pose a challenge to the procedural traditions of both adversarial and non-adversarial systems. We have seen that in both systems an active role for the defence during the investigation stage has been resisted. Adversarial systems consider that there is a role for the defence at the pre-trial stage but only largely in order to prepare for trial and non-adversarial systems have considered that the defence role only becomes active when the investigating judge or prosecutor becomes engaged. The Salduz principle enables suspects to be advised on their rights during police questioning but active defence participation at this stage has not been accepted. However, procedural traditions are capable of adapting to change in response to demands that they live up to underlying ideals of truth finding and fairness on which their legitimacy has depended. If criminal procedures are truly undergoing managerial changes that move the centre of gravity of adjudication from the trial towards the investigation stage, then the safeguards reserved for trial processes will have to be increasingly assigned to suspects at this stage. Such a transition will not be easy to achieve. We have seen that it took the most part of a century for the procedural traditions to accept an active role for the defence at trial. One commentator has considered that the question as to what safeguards can be devised for case resolutions without trial will dominate the procedural battles of the twenty first century. ${ }^{167}$ But now there are at least cosmopolitan influences at work which can play a role in

163 See Criminal Justice Act 2003, Pt 3, ss 22-27.

164 S. Thaman, 'Plea-Bargaining, Negotiated Confessions and Consensual Resolution of Criminal Cases' in K. Boele-Woelki and S. van Erp (eds), General Reports of the XVII Congress of the International Academy of Comparative Law (Brussels/Utrecht: Eleven International, 2007).

165 Germany CCP, s 257(c). See T. Weigend, 'The Decay of the Inquisitorial Ideal: Plea Bargaining Invades German Criminal Procedure' in Jackson at al, n 9 above, 39.

166 See French CPP, Arts 495-7-495-16; Italian CCP, Arts 444-48.

167 T. Weigend, 'Should We Search for the Truth, and Who Should Do It?' (2011) 36 North Carolina Journal of International Law \& Commercial Regulation 389, 415. 
facilitating change. Supra-national organs such as the ECtHR provide a forum where arguments can be made and where a positive lead can be taken. The Sal$d u z$ experience suggests that the ECtHR can influence procedural change not only in its capacity as the authoritative source of interpretation of Convention rights but also by acting as a forum for developing standards of fairness which are also deeply embedded in the procedural traditions of member states. 